\title{
Erratum: Pharmaceuticals as indictors of sewage-influenced groundwater
}

Beate Müller • Traugott Scheytt • Martin Asbrand • Andrea Mross de Casas

Erratum to: Hydrogeology Journal (2012), DOI 10.1007/s10040-012-0852-4

There is a spelling error in the title. The correct title is "Pharmaceuticals as indicators of sewage-influenced groundwater".

Published online: 7 July 2012

(C) Springer-Verlag 2012

The online version of the original article can be found at http://dx.doi.org/ $10.1007 / \mathrm{s} 10040-012-0852-4$.

B. Müller $(\bullet) \cdot$ T. Scheytt $\cdot$ M. Asbrand $\cdot$ A. M. Casas

Technische Universität Berlin, Department of Applied Geosciences, Hydrogeology Research Group,

Ernst-Reuter-Platz 1, 10587 Berlin, Germany

e-mail: beate@mailbox.tu-berlin.de

Tel.: +49-30-31472921

Fax: +49-30-31425674

T. Scheytt

e-mail: traugott.scheytt@tu-berlin.de 